\title{
VITAMIN D STATUS AND DIABETES MELLITUS
}

\author{
Dr. Mohammad Anwar Magsi', Dr. Aamir ljaz², Dr. Aaizah Maryam³ ${ }^{3}$ Dr. Shagufta Yousaf ${ }^{4}$, \\ Dr. Fawaad Sana ${ }^{5}$, Dr .Najamuddin ${ }^{6}$
}

1. Trainee FCPSII Chemical Pathology PNS SHIFA Hospital, Karachi 2. Professor Chemical Pathology PNS SHIFA Hospital, Karachi $3,4,5,6$.

PNS SHIFA Hospital, Karachi

Correspondence Address: Dr. Mohammad Anwar Magsi, Baloch Colony, Near Siddiqa Masjid Jan Muhammad Road, Quetta mohammadanwar20000@gmail.com

\begin{abstract}
Introduction: Diabetes mellitus is a worldwide epidemic, similarly low Vitamin D levels constitutes a largely unrecognized epidemic in many populations. There is no study in our country to document the association between these two common metabolic disorders. Objective: To assess the degree of correlation between vitamin D status and various categories of hyperglycaemia in a Pakistani population. Study Design: Descriptive cross sectional study. Place \& Period of Study: Department of Pathology, PNS SHIFA Hospital, Karachi; Jan 2013 to Aug 2013. Glucose levels were measured in eight six patients divided on the basis of their 25hydroxyvitamin D3 (25OHD) levels in three groups, normal (>31 ng/ml), insufficient $(20-31 \mathrm{ng} / \mathrm{ml})$ and deficient $(<20 \mathrm{ng} / \mathrm{ml})$. 25OHD was measured by electrochemiluminescence using Roche Elecsys ${ }^{\circledR}$ Systems while glucose was estimated by routine methods on Roche Hitachi ${ }^{\circledR}$ Autoanalyser. Results: Vitamin D levels were inversely correlated with plasma glucose levels $(r=0.38 ; p<0.01)$ with an Odd Ratio of 3.59 (95\%confidence interval 1.29 to 8.70). Fasting plasma glucose was significantly higher in vitamin $D$ deficient patients as compared to patients with normal vitamin D status $(p<0.05)$. Conclusions: Vitamin D deficiency is negatively associated with plasma glucose levels.
\end{abstract}

Key words: $\quad$ Vitamin D3; Diabetes mellitus.

Article Citation: Magsi MA, ljaz A, Maryam A, Yousaf S, Sana F, Najamuddin. Vitamin D status and diabetes mellitus. Professional Med J 2014;21 (3): 445-449.
Article received on:

27/09/2013

Accepted for Publication:

03/03/2014

Received after proof reading:

$27 / 05 / 2014$ however, pertains to Caucasian population while studies in African American have not confirmed these findings and the association between VDD and diabetes mellitus (DM) is quite blurred ${ }^{8}$. Asians have a high prevalence of both DM and VDD and the association of these two disorders has been described in studies carried out in Asian living in the West ${ }^{9}$. Vitamin D replacement therapy in South Asian patients with diabetes has also been shown to decrease in $\mathrm{HbA} 1 \mathrm{c}$ and weight ${ }^{10}$. Tehrani et al (2010) has shown that abnormal vitamin $\mathrm{D}$ concentrations were more common in South Asians with type 2 DM (T2DM) and diabetic control was inversely related to vitamin $D$ status in South Asian women with T2DM ${ }^{11}$. Conversely, Taylor and Wise (1997) have reported that vitamin $D$ replacement may increase the insulin resistance and worsen the glycaemic control in Asians ${ }^{12}$. Pakistan is one of the countries with a very high 
burden of diabetic patients and a very high prevalence of hypovitaminosis D. So present study has been planned to find an association between these two metabolic diseases.

\section{METHODS AND MATERIAL}

In this cross sectional study 86 subjects were selected by non-probability convenience sampling out of the patients referred for vitamin D estimation. The sample population consisted of patients with normoglycaemia (NG), impaired fasting glucose (IFG), and DM. NG was defined as Fasting Plasma Glucose (FPG) $<5.6 \mathrm{mmol} / \mathrm{L}$, IFG: $5.6-7.0 \mathrm{mmol} / \mathrm{L}$ and $\mathrm{DM}>7.0 \mathrm{mmol} / \mathrm{L}$ (Position Statement-American Diabetic Association2009)13. Similarly, on the basis of their $250 H D$ levels in blood the subjects were clustered in three groups, normal (>31 ng/ml), insufficient (20$31 \mathrm{ng} / \mathrm{ml}$ ) and deficient $(<20 \mathrm{ng} / \mathrm{ml}) 14$. 25OHD was measured by electrochemiluminescence using Roche Elecsys ${ }^{\circledR}$ Systems while glucose were estimated by routine methods on Roche Hitachi ${ }^{\circledR}$.

\section{STATISTICAL ANALYSES}

The data was recorded in SPSS version 17 and frequencies of various groups of subjects according to Vitamin D status were determined. Comparison of frequencies was carried out using Chi Square test and continuous data was compared by students ' $t$ test i.e. comparison of FPG in various groups of Vitamin D status. Then correlation studies were carried out between FPG and 25OHD levels using Pearson's Correlation Coefficient. VDD and VDI of vitamin D status groups were combined and IFG and DM of glucose categories were combined and then 2x2 table was constructed for comparison and calculation of Odds Ratio (OR) using chi-square test.

\section{RESULTS}

The sample population had a slight female preponderance (53\%), while median age was 34 years (range: 19- 65 years). DM was more frequent in subjects with VDD (50\% i.e. half of the patients with VDD were also having DM) and VDI (31.6\%) as compared to subjects with normal vitamin $D$ status (6.1\%) (Table-I). Similarly, more patients with IFG were found in VDD (25\%) and VDI (26.3\%) groups as compared to subjects with normal Vitamin D status (18.6\%) (Table-I). This difference was found statistically significant $(p<0.001)$. A gradual worsening of glycaemic condition was found on progressing from normal vitamin $D$ status to insufficiency and deficiency (Figure 1).

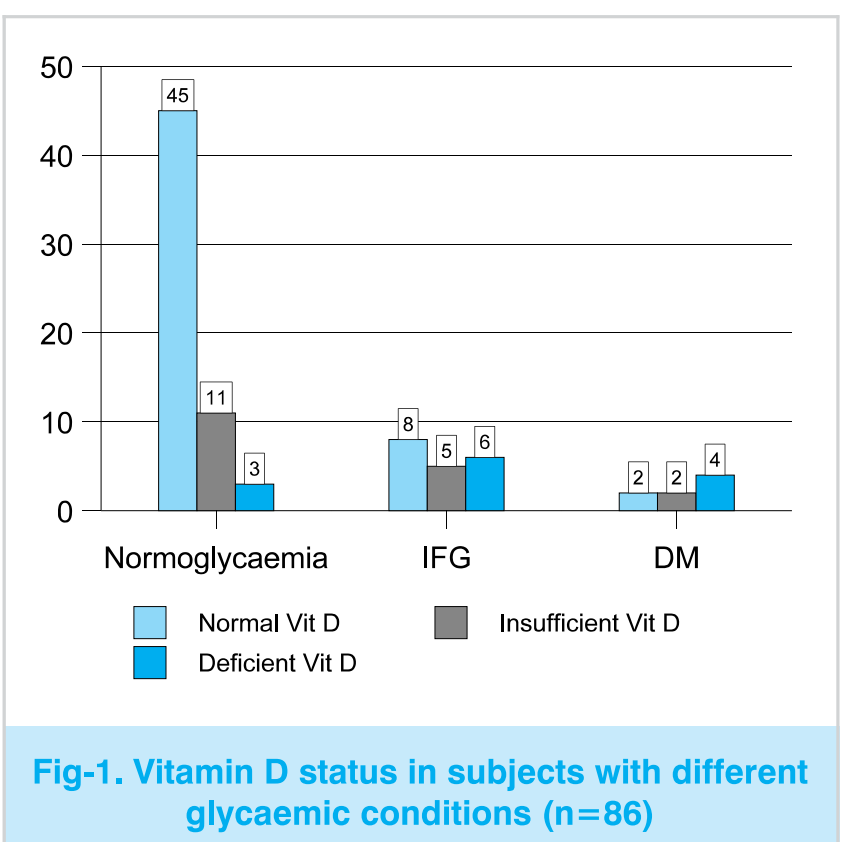

\section{DISCUSSION}

The association of Vitamin D and DM has been described for more than twenty five years now ${ }^{15}$. Many workers have shown evidence that vitamin D is related to various aspects of glucose metabolism e.g. improving beta-cell function of pancreas, insulin secretion and insulin sensitivity and is one of the most important environmental factors causing T2DM ${ }^{16-20}$. Our data has shown two significant findings i.e. higher prevalence of IFG and frank DM in patients with VDI and VDD, and a significance correlation of FPG and vitamin $D$ levels. Many cross-sectional studies carried out in Western populations have generally reported an inverse association between vitamin $D$ status and prevalent hyperglycemia ${ }^{21}$. Similar associations between higher fasting plasma glucose levels and vitamin D status were observed in a communitybased study of older adults without known diabetes $^{22}$. Expressing this association in another manner, Tahrani et al (2010) has shown that a low 


\begin{tabular}{|c|c|c|c|c|c|}
\hline Vitamin D Status & $\begin{array}{l}\text { No. of } \\
\text { subjects } \\
(n=86)\end{array}$ & $\begin{array}{l}\text { Normoglycaemia } \\
\text { (FPG <5.6 mmol/L) }\end{array}$ & $\begin{array}{c}\text { IFG } \\
(\text { FPG } 5.6-7.0 \\
\mathrm{mmol} / \mathrm{L})\end{array}$ & $\begin{array}{c}\text { DM } \\
\text { (FPG > 7.0 } \\
\mathrm{mmol} / \mathrm{L})\end{array}$ & $\begin{array}{c}\text { Significance } \\
\text { levels } \\
\text { (Chi square test) }\end{array}$ \\
\hline $\begin{array}{l}\text { Normal } \\
(>30 \mathrm{ng} / \mathrm{ml})\end{array}$ & $\mathrm{n}=59$ & $45(76 \%)$ & $11(18.6 \%)$ & $3(5.1 \%)$ & $\begin{array}{l}\text { Normal and } \\
\text { insufficiency group } \\
(p=<0.001)\end{array}$ \\
\hline $\begin{array}{l}\text { Insufficiency } \\
(20-30 \mathrm{ng} / \mathrm{ml})\end{array}$ & $n=19$ & $8(42.1 \%)$ & $5(26.3 \%)$ & $6(31.6 \%)$ & $\begin{array}{l}\text { Insufficiency and } \\
\text { deficiency group } \\
(p=<0.001)\end{array}$ \\
\hline $\begin{array}{l}\text { Deficiency } \\
(<20 \mathrm{ng} / \mathrm{ml})\end{array}$ & $\mathrm{n}=8$ & $2(25 \%)$ & $2(25 \%)$ & $4(50 \%)$ & $\begin{array}{c}\text { Normal and } \\
\text { deficiency group } \\
(p=<0.001)\end{array}$ \\
\hline \multicolumn{6}{|c|}{ Table-I. Distribution of various glycaemic groups in subjects with different Vitamin D Status } \\
\hline \multicolumn{6}{|c|}{ FPG: Fasting Plasma Glucose } \\
\hline
\end{tabular}

\begin{tabular}{|c|c|c|c|c|c|}
\hline Vitamin D Status & $\begin{array}{c}\text { No. of } \\
\text { subjects } \\
(n=86)\end{array}$ & $\begin{array}{c}\text { (FPG mmol/L) } \\
(\text { mean } \pm \text { SD) }\end{array}$ & $\begin{array}{c}\text { Significance } \\
\text { levels } \\
\text { (independent } \\
\text { t-test) }\end{array}$ & $\begin{array}{c}\text { Pearson's } \\
\text { correlation } \\
\text { (r-value) }\end{array}$ & $\begin{array}{c}\text { Significance } \\
\text { levels } \\
\text { ( } P \text { value) }\end{array}$ \\
\hline $\begin{array}{l}\text { Normal } \\
(>30 \mathrm{ng} / \mathrm{ml})\end{array}$ & $\mathrm{n}=59$ & $5.4 \pm 2.2$ & $\begin{array}{c}\text { Normal and } \\
\text { insufficiency Group } \\
(p=N S)\end{array}$ & \multirow{3}{*}{$r=-0.38$} & \multirow{3}{*}{$P<0.001$} \\
\hline $\begin{array}{l}\text { Insufficiency } \\
(20-30 \mathrm{ng} / \mathrm{ml})\end{array}$ & $n=19$ & $6.3 \pm 2.3$ & $\begin{array}{c}\text { Insufficiency and } \\
\text { Deficiency Group } \\
\quad(p=N S)\end{array}$ & & \\
\hline $\begin{array}{l}\text { Deficiency } \\
(<20 \mathrm{ng} / \mathrm{ml})\end{array}$ & $n=8$ & $8.1 \pm 3.8^{*}$ & $\begin{array}{c}\text { Normal and } \\
\text { Deficiency Group } \\
(p<0.05)\end{array}$ & & \\
\hline
\end{tabular}

\begin{tabular}{|l|c|c|c|}
\hline & \multirow{2}{*}{ OR } & \multicolumn{2}{|c|}{$95 \%$ Confidence Interval } \\
\cline { 3 - 4 } & & Lower & Upper \\
\hline $\begin{array}{l}\text { Odds ratio for } \\
\text { glucose level } \\
\text { (Normal / } \\
\text { abnormal) }\end{array}$ & 3.359 & 1.297 & 8.701 \\
N of Valid Cases & 86 & & \\
\hline \multicolumn{2}{|c|}{$\begin{array}{l}\text { Table-III. Risk Estimate of Vitamin D adequacy in } \\
\text { Normal and abnormal glucose levels }\end{array}$} \\
\hline
\end{tabular}

serum $250 H D(<20 \mathrm{ng} / \mathrm{ml})$ was more common in diabetics as compared to controls $(83 \%$ vs. $70 \%$; $p$ $<0.07)^{11}$. In another study from US, mean 25OHD levels among T2DM patients were found significantly lower than in individuals without T2DM (OR 1.85; 95\% Cl $1.03-3.32 ; \mathrm{P}=0.038)^{23}$. Conversely, in an Indonasian study $81 \%$ diabetic were found to be having VDD as compared to $75 \%$ non-diabetic (OR: 0.8; 95\% Cl $0.42-1.21$; $\mathrm{P}=$ $0.46)^{24}$ whereas our study showed an OR of 3.35 (95\% Cl: 1.29-8.70). This discrepancy is difficult to explain but is probably due to difference in age of the selected population.

The close association between vitamin status and DM has been further emphasized by the finding that inadequate vitamin $\mathrm{D}$ level is an important risk factor for the development of type $2 \mathrm{DM}^{25-28}$. The intervention studies to improve glycaemic control with certain doses of vitamin $\mathrm{D}$, however, have 
shown variable results ${ }^{29-30}$. Beneficial effect of vitamin $\mathrm{D}$ on T2DM is needed to be confirmed in large trials specifically designed to test the hypothesis that vitamin $D$ status is a direct contributor to the pathogenesis of T2DM. If such an intervention is clearly shown to be effective this could have substantial public health implications ${ }^{21}$.

This was the first study in our country in which an association of vitamin D status was studied with various categories of glucose abnormalities but with some limitations e.g. impaired glucose tolerance which is a category of hyperglycaemia based on oral glucose tolerance test could not be studied. Similarly data regarding glycosylated hemoglobin could not be recorded.

\section{CONCLUSIONS}

A significant association between diabetes mellitus and vitamin D inadequacy exists which implies that vitamin $D$ deficiency or insufficiency is undesirable in patients with any form of hyperglycaemia.

Copyright@ 25 Jan, 2014.

\section{REFERENCES}

1. Prentice A. Vitamin D deficiency: a global perspective: Nutrition Reviews 2008; 66:(2):S153154.

2. Holick MF. High Prevalence of Vitamin D Inadequacy and Implications for Health. Mayo Clin Proc. 2006;81(3):353-373.

3. Zuberi LM, Habib A, Haque N, Jabbar A. Vitamin D Deficiency in Ambulatory patients. J Pak Med Assoc 2008;58(9):482-484.

4. Iqbal $\mathrm{R}$, Khan $\mathrm{AH}$. Possible causes of vitamin D deficiency in Pakistani population residing in Pakistan: J Pak Med Assoc 2010;60(1):1-2.

5. Danescu LG, Levy S, Levy J. Vitamin D and diabetes mellitus: Endocr 2009; 35(1):11-17.

6. Mathieu C, Gysemans C, Giulietti A, Bouillon R. Vitamin $D$ and diabetes. Diabetologia 2005;48:1247-1257.

7. Forouhi NG, Luan J, Cooper A, Boucher BJ, Wareham NJ. Baseline serum 25-hydroxy vitamin $D$ is predictive of future glycemic status and insulin resistance. The Medical Research Council
Ely Prospective Study 1990 -2000. Diabetes 2008;57:2619-2625.

8. Scragg $R$, Sowers MF, Bell C. Serum 25Hydroxyvitamin D, Diabetes, and Ethnicity in the Third National Health and Nutrition Examination Survey. Diabetes Care 2004; 27:2813-2818.

9. Goswami, R, Mishra SK, Kochupillai N. Prevalence and potential significance of vitamin $D$ deficiency in Asian Indians. Indian J Med Res 2008; 127:229238.

10. Sabherwal S, V. Bravis V, Devendra D. Effect of oral vitamin $D$ and calcium replacement on glycaemic control in South Asian patients with type 2 diabetes. Int J Clin Pract 2010; 64(8): 1084-1089

11. Tahrani AA, Ball A, Shepherd L, Rahim A, Jones AF, Bates $A$. The prevalence of vitamin $D$ abnormalities in South Asians with type 2 diabetes mellitus in the UK. Int J Clin Pract 2010;64 (3):351-355.

12. Taylor AV, Wise $\mathrm{PH}$. Vitamin $\mathbf{D}$ replacement in Asians with diabetes may increase insulin resist a n c e. P o s t grad M ed $\mathrm{J}$. 1998;74(872):365-366.

13. Position Statement, American Diabetic Association. Diagnosis and Classification of Diabetes Mellitus. Diabetes Care 2009:32(S1):562-567.

14. Holick MF. Vitamin D Deficiency. N Engl J Med 2007; 357:266-268.

15. Gedik O, Akalin S. Effects of vitamin D deficiency and repletion on insulin and glucagon secretion in man. Diabetologia 1986; 29:142-145.

16. Allard P, Delvin EE, Paradis G, Hanley JA, O'Loughlin $J$, Lavallee $C$,et al. Distribution of fasting plasma insulin, free fatty acids, and glucose concentrations, and of homeostasis model assessment of insulin resistance in a representative sample of Quebec children and adolescents. Clin Chem 2003; 49: 644-649.

17. Pittas AG, Lau J, Hu FB, Dawson-Hughes B. The role of vitamin $D$ and calcium in type 2 diabetes. $A$ systematic review and metaanalysi s. J Clin Endocrinol Metab 2007; 92:2017-2029.

18. Ashraf A, Alvarez J, Saenz K, Gower B, McCormick $\mathrm{K}$, Franklin F. Threshold for effects of vitamin D deficiency on glucose metabolism in obese female African-American adolescents: J Clin Endocrinol Metab 2009; 94(9):3200-06. 
19. Grimnes G, Figenschau Y, Almas B, Jorde R. Vitamin $D$, insulin secretion, sensitivity, and lipids results from a case-control study and a randomized controlled trial using hyperglycemic clamp technique. Diabetes 2011;60(11):2748-2757.

20. Rajkumar KL, Holick MF, Heras JDL, Arsalani SA, Lee SJ. 25-Hydroxyvitamin D concentrations and in vivo insulin sensitivity and beta-Cell function relative to insulin sensitivity in black and white youth. Diabetes 2012;35(3):627-633.

21. Mitri J, Pittas AG. Vitamin D and type 2 diabetes: a systematic review. European Journal of Clinical Nutrition 2011; 65(9): 1005-1015.

22. Oh JY, Barrett-Connor E. Association between vitamin $D$ receptor polymorphism and type 2 diabetes or metabolic syndrome in communitydwelling older adults: the Rancho Bernardo Study. Metabolism 2002; 51:356-359.

23. Szep Z, Guaraldi G, Shah SS, Lo Re V 3rd, Ratcliffe SJ, Orlando G, et al. Vitamin D deficiency is associated with type 2 diabetes mellitus in HIV infection. AIDS. 2011;25(4):525-529.

24. Hidayat R, Setiati S, Soewondo P, The Association Between Vitamin D Deficiency and Type 2 Diabetes Mellitus in Elderly Patients. Acta Med Indones 2010;42(3):123-129.

25. de Boer IH, Tinker LF, Connelly S, Curb JD, Howard BV, Kestenbaum B et al. Calcium plus vitamin D supplementation and the risk of incident diabetes in the Women's Health Initiative. Diabetes Care 2008;31;701-707.

26. Liu E, Meigs JB, Pittas AG, Economos CD, McKeown NM, Booth SL et al. Predicted 25-hydroxyvitamin D score and incident of type 2 diabetes in the Framingham Offspring Study. Am J Clin Nutr 2010;91:1627-1633.

27. Liu S, Song Y, Ford ES, Manson JE, Buring JE, Ridker PM. Dietary calcium, vitamin D, and the prevalence of metabolic syndrome in middleaged and older US women. Diabetes Care 2005; 28:2926-2932.

28. Pittas AG, Dawson-Hughes B, Li T, Van Dam RM, Willett WC, Manson JE et al. Vitamin D and calcium intake in relation to type 2 diabetes in women. Diabetes Care 2006;9:650-656.

29. von Hurst PR, Stonehouse W, Coad J. Vitamin D supplementation reduces insulin resistance in South Asian women living in New Zealand who are insulin resistant and vitamin $\mathrm{D}$ deficient - a randomised, placebo-controlled trial. $\mathrm{Br} \mathrm{J}$ Nutr 2010;103, 549-555.

30. Jorde R, Figenschau Y. Supplementation with cholecalciferol does not improve glycaemic control in diabetic subjects with normal serum 25-hydroxyvitamin D levels. Eur J Nutr 2009;48:349-354.

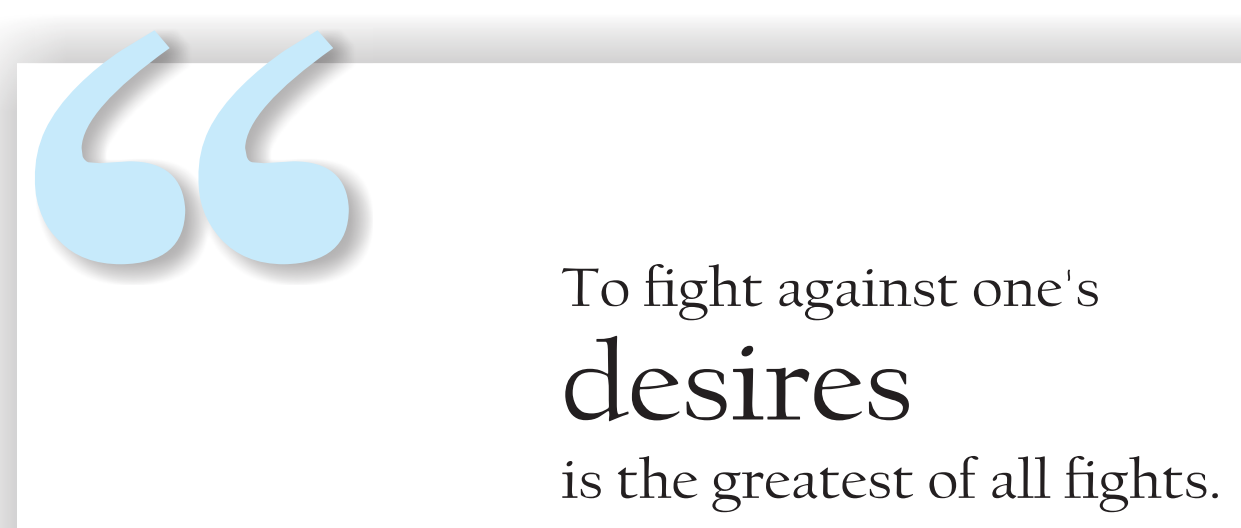

Hazrat Ali (R.A) 